Poznańskie Studia Teologiczne 30(2016), s. 353-368. doi: $10.14746 /$ pst.2016.30.17

\author{
Bogusław Kochaniewicz* \\ Uniwersytet im. Adama Mickiewicza w Poznaniu \\ Wydział Teologiczny
}

\title{
Świętość Kościoła w ujęciu św. Piotra Chryzologa
}

Jednym z tematów podejmowanych przez współczesnych badaczy jest eklezjologia ojców Kościoła. Osiagnięte w ten sposób wyniki badań poszerzają nasz obraz tajemnicy Kościoła o dorobek myślicieli chrześcijańskiego antyku. Obok prac o charakterze syntetycznym, ukazujących specyfikę eklezjologii danej epoki, istnieją opracowania podejmujące zagadnienia szczegółowe: analizujące aspekty nauki o Kościele wybranych autorów wczesnochrześcijańskich. Jednym z nich jest św. Piotr Chryzolog, biskup Rawenny (380-450), autor 184 kazań ${ }^{1}$. Chociaż jego nauka o Kościele była już przedmiotem analiz Bernarda Palardy'ego, to jednak owoc jego badań, dysertacja doktorska, przechowywana w formie mikrofilmu w bibliotece Catholic University of America w Waszyngtonie, pozostaje dla europejskiego czytelnika niedostępna ${ }^{2}$. Specyficzny aspekt eklezjologii Chryzologa podejmuje monografia Giuseppe Scimègo, który analizując związki pomiędzy Żydami a chrześcijanami w Rawennie $\mathrm{V}$ wieku, zwraca uwagę na temat Ecclesia-Synagoga pojawiający się w kazaniach biskupa Rawenny ${ }^{3}$. Kolejne opracowanie autorstwa Maria Spinellego zostało poświęcone symbolice eklezjalnej Złotosłowego kaznodziei ${ }^{4}$.

Polskojęzyczne publikacje dotyczące interesującej nas tematyki obejmują prace Dariusza Kasprzaka ${ }^{5}$ oraz Jerzego Wojtczaka ${ }^{6}$. Pierwszy z wymienionych

* Bogusław Kochaniewicz, dominikanin, redaktor „Poznańskich Studiów Teologicznych”.

${ }^{1}$ Edycja krytyczna kazań: Petrus Chrysologus, Sancti Petri Chrysologi Collectio sermonum a Felice Episcopo parata, sermonibus extravagantibus adiectis, ed. A. Olivar, w: Corpus Christianorum. Series Latina, voll. 24, 24A, 24 B, Tournholti 1975, 1981, 1982. Na powyższej edycji opiera się włoskie tłumaczenie kazań Chryzologa. San Pietro Crisologo, Sermoni, ed. A. Olivar, G. Banterle, R. Benericetti, G. Biffi, G. Scimè, C. Truzzi, (=Opere di San Pietro Crisologo. Scrittori dell'Area Sant'ambrosiana), voll. I-III, Biblioteca Ambrosiana-Città Nuova Editrice, Milano-Roma 1996-1997.

${ }^{2}$ B. Palardy, The Church and the Synagogue in the Sermons of St. Peter Chrysologus, Washington 1992.

${ }^{3}$ G. Scimè, Giudei e cristiani nei sermoni di san Pietro Crisologo, Roma 2003.

${ }^{4}$ M. Spinelli, La simbologia ecclesiologica di Pier Crisologo, w: Sangue e antropologia biblica nella patristica, ed. F. Vattoni, Roma 1982, s. 547-562.

${ }^{5}$ D. Kasprzak, Duszpasterze V wieku. Studium porównawcze myśli pasterskiej św. Piotra Chryzologa i Salwiana z Marsylii. Kraków 2008, (szczególnie s. 124-156).

${ }^{6}$ J. Wojtczak, Kościól jako «grex»w Sermones Piotra Chryzologa, w: Kościót, świat i zbawienie we wczesnym chrześcijaństwie, red. J. Naumowicz, Warszawa 2004, s. 154-158. 
ukazał duszpasterską troskę Salwiana z Marsylii i Piotra Chryzologa, opierając się na analizie ich homilii. W tym kontekście przedstawił syntetyczne ujęcie eklezjologii biskupa Rawenny. Artykuł drugiego autora koncentruje uwagę na specyficznym aspekcie symboliki eklezjologicznej obecnym w kazaniach Piotra z Rawenny. Rozpatrywana w tym kontekście kwestia świętości Kościoła została przebadana jak dotąd w niewielkim stopniu.

\section{Biblijna symbolika Kościoła w kazaniach Piotra Chryzologa}

Jedną z charakterystycznych cech eklezjologii biskupa Rawenny zawartej w jego homiliach jest bogata symbolika biblijna. Dzięki zastosowanej egzegezie alegorycznej wiele obrazów zaczerpniętych z Pisma św. zostało odniesionych do tajemnicy Kościoła. Zanim zostanie podjęty główny temat niniejszego opracowania, warto przedstawić najważniejsze elementy wspomnianej symboliki eklezjalnej, które będą stanowić kontekst podejmowanej analizy.

Kościół jest domem Ojca, który gromadzi wiernych, modlących się słowami modlitwy Pańskiej ${ }^{7}$. Wspólnota wierzących została także porównana do łodzi (navis Christi), w której obecny jest Chrystus, prowadzący barkę przez wzburzone odmęty morza do portu zbawienia. W kazaniu 50 Piotr Chryzolog stwierdza: „Chrystus zatem nie potrzebuje łodzi, lecz to łódź potrzebuje Chrystusa, bez tego niebiańskiego sternika, łódź Kościoła, poprzez wzburzone morze świata, wśród wielu różnych niebezpieczeństw, nie byłaby w stanie dotrzeć do niebiańskiego portu" ${ }^{8}$. Kilkakrotnie chrześcijanie zostali porównani do żołnierzy prowadzących walkę pod przywództwem Chrystusa Króla z Szatanem9.

W symbolice eklezjalnej biskupa Rawenny bardzo często pojawia się postać niewiasty. W tym ujęciu dwie Marie podążające do grobu Pańskiego symbolizują Kościół złożony z Żydów i z pogan ${ }^{10}$. Niewiasta, której Jezus odpuścił wiele grzechów (Łk 7,37), wskazuje na grzeszną kondycję Kościoła ${ }^{11}$. Natomiast cu-

${ }^{7}$ Piotr Chryzolog, Sermo 5,6. CCL 24, 39: „Redit autem ad patrem, et clamat: «Pater, peccavi in caelo et coram te». Redisse iuniorem ad domum patris, et clamare deum patrem, vox ecclesiae cotidiana testatur, quae dicit: «Pater noster, qui es in caelis»”. Podobne określenie Kościoła zob. Sermo 3,2. CCL 24, 27. Por. M. Spinelli, La simbologia ecclesiologica di Pier Crisologo, w: Sangue e antropologia biblica nella patristica, ed. F. Vattoni, Roma 1982, s. 547-548.

${ }^{8}$ Sermo 50,2. CCL 24, 278: „Non ergo Christus indiget nave, sed navis indiget Christo, quia sine caelesti gubernatore navis ecclesiae per mundanum pelagus tali et tanto discrimine ad caelestem portum non valet pervenire". Por. M. Spinelli, La simbologia, s. 550-553.

${ }^{9}$ Sermo 13,2. CCL 24, 82; Sermo12,3. CCL 24, 78. Por. M. Spinelli, La simbologia, s. 554-556.

${ }^{10}$ Sermo 75, 3. CCL 24A, 459-460: ,Sed non hinc faciunt apostolos segnores, quae non feminarum formas, sed ecclesiarum typum dominicum deferunt ad sepulchrum. Maria et Maria: sic altera ut ipsa, ipsa ut altera, Maria, maternum Christi unum nomen, duas geminatur in feminas, quia hic ecclesia ex duobus populis veniens, una figuratur ex duobus populis, id est ex gentibus et Iudaeis".

${ }^{11}$ Sermo 95, 4. CCL 24A, s. 587: „Et ecce, inquit, mulier, quae erat in civitate peccatrix. Quae mulier? Ecclesia sine dubio". 
downie uzdrowiona $\mathrm{z}$ upływu krwi kobieta jest figurą wspólnoty wierzących, żyjącej w nowej ekonomii zbawczej, opartej na prymacie Bożej łaski ${ }^{12}$.

\section{Chrystus - fundamentem świętości Kościoła}

W pierwszych wiekach chrześcijaństwa świętość Kościoła była łączona z obecnością Ducha Świętego. W dziele Adversus haereses św. Ireneusz z Lyonu stwierdzał: „tam gdzie jest Kościół tam również Duch Święty, a gdzie Duch Święty tam Kościół i wszelka łaska"'13. Natomiast Orygenes położył akcent na cnoty, owoc działania Bożego Ducha, które ubogacały Lud Boży, będąc oznaką jego świętości. Kościół, jego zdaniem, jest święty nie tyle z powodu braku jakiejkolwiek skazy $^{14}$, ile ze względu na obecność cnót: wiary, niewinności, cierpliwości, dziewictwa, miłości, nadziei ${ }^{15}$. Podobną refleksję, wskazującą na wymiar moralny Kościoła jako owoc działania Ducha Świętego w Kościele, rozwijał zarówno Tertulian $^{16}$, jak i Cyprian z Kartaginy ${ }^{17}$.

Stanowisko tego ostatniego, zajęte w sporze $\mathrm{z}$ donatystami, zostało skorygowane przez papieża Stefana, który, zamiast ukazywać świętość Kościoła w perspektywie pneumatologicznej, zaproponował inną, chrystocentryczną ${ }^{18}$. W tym ujęciu „fundamentem obecności Ducha Świętego, który decyduje o świętości Kościoła, [...] jest osoba Chrystusa, Który przekazuje Kościołowi swojego Ducha"19.

Przedstawiona przez papieża nowa, chrystocentryczna interpretacja świętości Kościoła, została przyjęta w IV stuleciu (Optat z Milewy ${ }^{20}$, Hieronim ${ }^{21}$ ), a następnie rozpowszechniona i utrwalona $\mathrm{w}$ następnym ${ }^{22}$. Od tej pory dla auto-

12 Sermo 105, 7. CCL 24A, 653-654: „Quia nisi decalogus legis ogdoadis venisset ad gratiam, numquam sancta ecclesia, numquam mulier haec ad plenitudinem temporis ad diem salutis, ad tempus acceptum, ad sui salvatoris presentiam pervenisset. Hanc autem mulierem portasse ecclesiae sic figuram ipsius qualitas curationis adsignat".

${ }^{13}$ Ireneusz z Lyonu, Adversus haereses III, 24, 1. PG 7, 966. „Ubi enim Ecclesia, ibi et Spiritus Dei, et ubi Spiritus Dei, illic Ecclesia et omnis gratia: Spiritus autem Veritas".

${ }^{14}$ Orygenes, In Exodum. Homilia IX, 3. PG 12, 364.

15 Tamże, PG 12, 365.

16 Tertulian, De baptismo 4-5. CCL 1, s. 279-282. Por. W. Prus, Spór o «Ecclesia sancta» w Afryce na podstawie łacińskich przekazów patrystycznych z III i IV wieku, Poznań 2013, s. 195.

${ }^{17}$ Por. Cyprian, Epistula 73,11. CCL 3, s. 541-542. Por. W. Prus, Spór o «Ecclesia sancta», dz. cyt., 118, 195.

${ }^{18}$ Cyprian w swoich listach referuje stanowisko papieża Stefana. Zob. Cyprian, Epistula 75 , 18. CCL 3, s. 597-598. Por. W. Prus, Spór o «Ecclesia sancta», dz. cyt., 121, 195.

${ }^{19}$ W. Prus, Spór o «Ecclesia sancta», dz. cyt., s. 195.

${ }^{20}$ Zob. Optat z Milewy, Traité contre les Donatistes, V, 7. SCh 413, Paris 1996, s. 142-150.

Por. W. Prus, Spór o «Ecclesia sancta», dz. cyt., s. 195.

${ }^{21}$ Zob. H. Bogacki, Kościót jako Ciało Mistyczne wedtug św. Hieronima, „Roczniki Teologiczno-Kanoniczne" 5 (1958), z. 4, s. 37-53.

${ }^{22}$ Zob. W. Staniszewski, Kościót jako Ciało Mistyczne Chrystusa według św. Augustyna, Lublin 1936 . 
rów chrześcijańskiego antyku obecność Chrystusa w Kościele stanowiła trwały fundament jego świętości.

Taką właśnie koncepcję odnajdujemy z kazaniach św. Piotra Chryzologa: „Wierzymy w święty Kościół, który Chrystus zjednoczył z sobą, aby w ten sposób stał się uczestnikiem Jego bóstwa"23. Z przytoczonych powyżej słów kaznodziei wynika, że Chrystus jest fundamentem ontologicznej świętości Kościoła. Dla podkreślenia tej prawdy biskup Rawenny określał Kościół jako M i s t y c z ne ciało Chrystusa oraz Oblubienicę Chrystusa.

\section{a) Kościól - Mistyczne Ciało Chrystusa}

Określenie Kościoła jako ciała Chrystusa było znane myślicielom wschodnim IV stulecia: św. Janowi Chryzostomowi ${ }^{24}$ czy św. Bazylemu Wielkiemu ${ }^{25}$. Na Zachodzie ujęcie to pojawia się w jednym z listów św. Ambrożego, który zwracał uwagę, że powinniśmy kochać innych ze względu na nasze zjednoczenie z Chrystusem, jako że tworzymy jedno ciało, którego Jezus jest głową ${ }^{26}$.

Wspomniana interpretacja jest obecna również w przepowiadaniu biskupa Rawenny. Określenie ciała Chrystusa odniesione do Kościoła wskazuje na fundament jego świętości. W kazaniu 62bis, będącym wykładem Symbolu Apostolskiego, Piotr Chryzolog wyznaje: „Święty Kościót. Ponieważ jest on (Kościół) ciałem Chrystusa, którego głową jest Chrystus, zatem wyznajemy Chrystusa w świętym Kościele"27. Jak można zauważyć, świętość Kościoła wynika ze ścisłej więzi łączącej Chrystusa (głowę) z Eklezją (Jego ciałem), co jest gwarantem Jego uświęcającej obecności. Podobna refleksja pojawia się w kazaniu 76: ,Jednocześnie ponieważ Chrystus w Kościele pozdrawia samego siebie, dokonał tego w ten sposób, aby Jego Kościół był Jego wnętrznościami, przyjął do swojego ciała, o czym mówi Apostoł: «On jest głową ciała, czyli Kościoła»"28.

Tajemnica więzi płynącej ze zjednoczenia Chrystusa z Kościołem zostaje rozwinięta i przeniesiona na grunt pobożności chrześcijańskiej. W homilii 132 biskup Rawenny, przeciwstawiając się indywidualistycznej pobożności wiernych, gorąco ich zachęca do obecności na zebraniach liturgicznych.

\footnotetext{
${ }^{23}$ Piotr Chryzolog, Sermo 60,14. CCL 24, s. 340: „Credimus sanctam ecclesiam, quam sic in se suscepit Christus, ut eam divinitatis suae faceret esse consortem”.

${ }^{24}$ Jan Chryzostom, In Epistolam I ad Corinthios, Homilia XXXII, 1. PG 61, 263.

${ }^{25}$ Bazyli Wielki, Homilia super Psalmum XLIV, 10, PG 29, 409.

${ }^{26}$ Ambroży, Epistula LXXVI, 12, PL 16, 1262: „,...] sed etiam in operibus sequatur suis, et aedificationem charitatis in se suscipiat: ut in unitate fidei et agnitionis occurrat, et quasi membrum non desit capiti suo, id est Christo, qui est caput omnium”. Por. E. Dublanchy, L'Eglise, w: Dictionnaire de Theologie Catholique, t. 4, pars 2, kol. 2152.

${ }^{27}$ Sermo 62bis,11. CCL 24, s. 355: „Sanctam ecclesiam. Qua ipsa est corpus Christi, et ipsius caput est Christus. Christum ergo in sancta ecclesia confitemur".

${ }^{28}$ Sermo 76, 2. CCL 24A, s. 466: „Simul quia Christus in ecclesia se salutat, suam sua fecit esse sic viscera, suum sic recepit in corpus, dicente apostolo: «Et ipse est caput corporis ecclesiae»”.
} 
Gdzie są ci, którzy zaniedbują zebrania Kościoła i uważają, że większą wartość mają modlitwy samotne, indywidualne niż czcigodne zebranie, skoro Chrystus obiecuje być obecnym pośród dwóch lub trzech zjednoczonych w jego imię i udzielić wszystkiego, o co zostanie poproszony? Czego nie dałby wielu? Czego odmówiłby tym, którzy Go o to proszą we wspólnotach i na zebraniach świętych ${ }^{29}$.

Powyższe słowa potwierdzają, że według Złotosłowego kaznodziei obecność Chrystusa pośród chrześcijan uczestniczących w liturgii jest źródłem niebieskich darów.

\section{b) Kościół - Oblubienica Chrystusa}

Powiązanie Chrystusa z Eklezją wyrażano także za pomocą obrazu oblubieńczego zjednoczenia Boskiego Oblubieńca z Oblubienicą-Kościołem.

Określenie Kościoła jako oblubienicy Chrystusa pojawia się między innymi w pismach Orygenesa ${ }^{30}$, św. Bazylego Wielkiego ${ }^{31}$, św. Jana Chryzostoma ${ }^{32}$ czy św. Augustyna ${ }^{33}$.

Określenie sponsa Christi pojawia się również w sermones Piotra z Rawen$n^{34}$. Użycie tego pojęcia w odniesieniu do Kościoła podkreślało ścisłe i trwale zjednoczenie Ludu Bożego z Chrystusem. W homilii 61 Piotr Chryzolog wyznaje: „Wierzę w święty Kościół. Abyś wyznał, że Kościół, oblubienica Chrystusa, pozostanie w wieczystej wspólnocie Chrystusa"35. W kolejnym kazaniu autor ten podkreśla konsekwencje tego zjednoczenia: „Ponieważ ani członki nie są oddzielone od głowy, ani oblubienica od oblubieńca, lecz dopóki przez takie połączenie staje się jeden duch, Bóg staje się wszystkim we wszystkich"36.

Interpretacja Kościoła jako oblubieńczego związku z Chrystusem opiera się na tekstach biblijnych (J 3,29; 2 Kor 11,2). „Oblubienica jest wzięta, aby już

${ }^{29}$ Sermo 132,4. CCL 24B, s. 811-812: „Ubi sunt qui ecclesiae conventum praesumunt posse contemni, et solitarias preces venerandae congregationi autumant anteferri, si duobus vel tribus compositis medium se futurum, et omnia se plurimis?"

${ }^{30}$ Orygenes, In Canticum canticorum, III, II, 5. PG 13, 161.

${ }^{31}$ Bazyli Wielki, Homilia super Psalmum XLIV, 11, PG 29, 412.

${ }^{32}$ Jan Chryzostom, In espistolam ad Ephesios. Homilia XX, 2, PG 62, 138.

${ }^{33}$ Augustyn, Epistula CXL, 18, PL 33, 545: „Haec ex persona sui corporis Christus dicit, quod est Ecclesia. Haec ex persona dicit infirmitatis carnis peccati, quam transfiguravit in eam quam sumpsit ex Virgine, similitudinem carnis peccati. Haec Sponsus ex persona sponsae loquitur, quia univit eam sibi quodam modo".

${ }^{34}$ Piotr Chryzolog, Sermo 61,12. CCL 24, s. 344: „Credo in sanctam ecclesiam: ut confitearis ecclesiam Christi sponsam in perpetua Christi societate mansuram”.

${ }^{35}$ Por. Piotr Chryzolog, Kazanie VI o Symbolu (Sermo 61, 13), w: Symbol Apostolski w naисzaniu Ojców, thum. L. Gładyszewski, Kraków 2010, s. 165.

${ }^{36}$ Piotr Chryzolog, Kazanie II o Symbolu (Sermo 57), w: Symbol Apostolski w nauczaniu Ojców, dz. cyt., s. 137. Zob. Piotr Chryzolog, Sermo 57,13. CCL 24, s. 323: „Quia neque a capite membra, neque sponsa separatur a sponso, sed dum tali coniuctione spiritus fit unus, fit omnia et in omnibus deus". 
wtedy został określony Kościół jako oblubienica Chrystusa według słów proroka Ozeasza: «Poślubię cię przez sprawiedliwość i prawo, przez miłość i miłosierdzie, poślubię cię sobie przez wierność» (Oz 2,21-22). Podobnie mówi Jan: «Ten, kto ma oblubienicę ten jest oblubieńcem» (J 3,29). Tak samo Paweł: «Poślubiłem was jednemu mężowi, by was przedstawić Chrystusowi jako czystą dziewicę» $(2$ Kor 11,2). Kościół jest oblubienica, która w dziewiczym narodzeniu rodzi nowe dzieci Chrystusa" ${ }^{77}$.

Pojęcie sponsa Christi pozwoliło Chryzologowi podkreślić rolę wiary i miłości w oblubieńczym związku. Scena objawienia się Zmartwychwstałego niewiastom, będącym figurą Kościoła, została zinterpretowana w perspektywie oblubieńczej. „W dwóch niewiastach posyła Kościół. [...] Wychodzi na spotkanie. Nie przeraża ich swoją mocą, lecz uprzedza ogniem miłości, nie niepokoi swoim autorytetem, lecz je pozdrawia, podporządkowuje je prawu oblubieńca, a nie według prawa zarządcy, pozdrawia je z czułością męża"38.

Rozwijając ten wątek, kaznodzieja zauważył różny stopień zjednoczenia wiernych z Chrystusem poprzez wiarę.

Ta sama rzeczywistość ukazuje w oczywisty sposób, że w owych niewiastach znajduje się kompletny obraz Kościoła. Chrystus karci swoich uczniów, że byli chwiejni w wierze w Jego zmartwychwstanie, jednocześnie umacnia ich, ukazując swój bok, ślady gwoździ na swoich rękach, a poprzez przyjęcie od nich pokarmu, przywraca im wiarę. Dlatego słusznie nazywa ich dziećmi, niedoskonałymi w wierze, zapytując ich: „Dzieci, macie coś do jedzenia?” W innym fragmencie nazywa „kobietą” tę samą Marię, która płakała nad nim, jak nad zmarłym, i nie pozwala jej, aby go dotknęła. Lecz wspomniane dwie niewiasty znajduje tak doskonałe i pełne wiary, tak nieustraszone i biegnące w kierunku tajemnicy, do tego stopnia poszukujące Pana z całym płomieniem ich wiary, że powierza się w ich ręce, pozdrawiając: „Pokój wam”, to znaczy miejcie mnie ${ }^{39}$.

${ }^{37}$ Piotr Chryzolog, Homilia o narodzeniu Chrystusa, tłum. W. Kania, w: Ojcowie Kościoła tacińscy. Teksty o Matce Bożej, t. 2, Niepokalanów 1981, s. 146. Por. tenże, Sermo 146, 5. CCL 24B, s. 904: „Sponsa quaeritur, ut iam tunc ecclesia Christi sponsa signetur, iuxta illud Oseae prophetae: «Sponsabo te mihi in iudicio et iustitia; sponsabo te mihi in misericordia et miserationibus, et desponsabo te mihi in fide». Hinc Iohannes ait: "Qui habet sponsam, sponsus est». Et beatus Paulus: «Sponsavi vos uni viro, virginem castam exhibere vos Christo». Vere sponsa, quae virginali partu novam Christi regignit infantiam".

${ }^{38}$ Sermo 76,2. CCL 24A, s. 465: „Occurrit, et non potestate terret, sed prevenit caritatis ardore, non auctoritate turbat, sed salutat: lege sponsi non dominantis iure onerat, sed honorat dilectione consortis".

${ }^{39}$ Sermo 76,2. CCL 24A, s. 466: „In istis vero feminis ecclesiae figuram manere plenam res ipsa ostendit evidenter, quia discipulos suos Christus de resurrectione nutantes arguit, trepidentes firmat ostensione lateris, clavorum cavernis, adsumptione cibi vix revocat ad fidem. Unde et merito in fide parvulos sic pueros appellat discendo «Pueri, habetis pulmentarium»? Ipsamque alibi Mariam flentem quasi de mortuo mulierem vocat, atque tangendi se licentiam negat, istas autem sic perfectas invenit, sic credentes, sic non de sexu trepidantes, sed mysterio currentes, sic dominum toto fidei ardore requirentes, ut habendum se tradat eis salutatione tali «Avete», hoc est, habetote". 
Na uwagę zasługuje, że podobną koncepcję zjednoczenia wiernych w jednym Duchu, wyraził św. Grzegorz z Nazjanzu. Według kapadockiego teologa w doskonałym ciele, którego Jezus jest głową, członki odznaczają się różnym stopniem doskonałości. Jedne, z powodu ściślejszego zjednoczenia z Bogiem oraz osiagnniętego wysokiego stopnia cnót, są porównane do duszy, inne, mniej doskonałe, zostały porównane do ciała. Wszystkie jednak są jednoczone za pomocą tego samego Ducha, w jednym Chrystusie ${ }^{40}$.

Chryzolog, kontynuując swoją refleksję, stwierdził, że oblubieńcze zjednoczenie Kościoła z Chrystusem staje się źródłem jego świętości. W kazaniu 57, będącym wykładem Symbolu apostolskiego, wyznał między innymi: „W święty Kościół. Ponieważ ani członki od głowy, ani oblubienica od oblubieńca nie jest oddzielona, lecz dopóki przez takie połączenie staje się jeden duch, Bóg staje się wszystkim we wszystkich" ${ }^{41}$.

Boski Oblubieniec, jednocząc się z Eklezją-oblubienica, przyozdabia Ją swoimi darami: cnotami wiary, mądrości, czystości, wstydliwości, dziewictwa. W tej perspektywie świątynia, będąca miejscem zebrania liturgicznego Ludu Bożego, jawi się jako komnata, w której odbywają się gody.

Od kiedy Chrystus przyszedł poślubić swój Kościół przyozdabia się komnatę godową oblubienicy, przyozdabia się złotem wiary, srebrem mądrości, diademami cnót, welonami świętości, różami skromności, liliami czystości, fiołkami przyzwoitości i świątynia wstydliwości zostaje wyniesiona wysoko do nieba na szczyt dziewictwa ${ }^{42}$.

Owocem zjednoczenia Chrystusa i Kościoła, wyrażonego za pomocą obrazu oblubieńca i oblubienicy, jest uświęcenie, obdarowanie Eklezji wieloma duchowymi darami.

\section{Uświęcająca misja Kościoła}

\section{a) Kościół - matka i dziewica}

Należy zauważyć, że Kościół jest nie tylko podmiotem uświęcanym, lecz również wspólnotą, która uświęca. Jego uświęcająca rola została wyrażona za pośrednictwem kategorii duchowego macierzyństwa, które zostało zarysowane w starotestamentalnych figurach niewiast: Rebeki, Tamar i Rut.

${ }^{40}$ Grzegorz z Nazjanzu, Oratio II, 3. PG 35, 409.

${ }^{41}$ Piotr Chryzolog, Kazanie II o Symbolu, w: Symbol Apostolski w nauczaniu Ojców, dz. cyt., s. 137. Piotr Chryzolog, Sermo 57,13. CCL 24, s. 323: „Sanctam ecclesiam. Quia neque a capite membra, neque sponsa separatur a sponso, sed dum tali coniunctione spiritus fit unus, fit omnia et in omnibus deus. Ergo ipse in deum credit, qui in deum sanctam ecclesiam confitetur".

${ }^{42}$ Sermo 22,6. CCL 24, s. 132-133: „Ex quo ad disponsandum ecclesiam suam Christus advenit, thalamus ornatur sponsae, et ornatur auro fidei, argento sapientiae, virtutum gemmis, sanctitatis velis, verecundiae rosis, liliis castitatis, pudoris violis, et ad alta caeli pudicitiae templum, ad fastigium virginitatis, attolitur". 
Szczęśliwa matka Kościół, która was w ten sposób kontempluje, i pozostając dziewicą, dziwi się, że was porodziła tak szlachetnych, w tak cudowny sposób. Starożytne przykłady były zapowiedzią tych narodzin. Oto dlaczego Jakub walczy w łonie i kradnie także triumfy. Oto dlaczego w łonie Tamar bliźniaki biją się o zaszczyt bycia pierworodnym, opóźniają poród, nie chcą ujrzeć światła zanim nie zwyciężą. Oto dlaczego Jan przed wyjściem z łona matki raduje się i spotyka swojego Stworzyciela ${ }^{43}$.

Narodziny do życia nadprzyrodzonego wiernych były przedstawiane jako owoce uświęcającej aktywności Kościoła, wyrażającej się w sprawowaniu sakramentów ${ }^{44}$. Biskup Rawenny, wyjaśniając katechumenom słowa Modlitwy Pańskiej, zwrócił między innymi uwagę na relację synowską do Boga Ojca, którą winien kultywować chrześcijanin, ponieważ jest ona owocem, konsekwencją przyjęcia sakramentu chrztu ${ }^{45}$. Podobne synowskie odniesienie winno charakteryzować chrześcijanina wobec Kościoła-Matki ${ }^{46}$.

W podobnym kluczu - Kościoła jako matki rodzącej swoje dzieci - została ukazana konsekracja biskupia. Chryzolog, udzielając święceń Marcelinowi, powiedział:

Marcelin zaskarbił sobie dzisiaj wszelkie uczucie, gdy chodzi o poród domowy. Stoją wokół niego synowie, są obecni bliscy, gromadzą się krewni, raduje się cała rodzina, ponieważ zasłużyli dzisiaj, aby zobaczyć na własne oczy, aby wziąć w ramiona pierworodnego świętej rodzicielki. Również sama rodzicielka, oblubienica, matka i dziewica dziwi się, że porodziła w komnacie swojego oblubieńca, w komnacie godowej $^{47}$.

${ }^{43}$ Sermo 72,3. CCL 24A, s. 431: „Ecclesia felix mater, quae vos tales respicit, quae cum virgo permanet, genuisse tantos vos et taliter se miratur. Olim partus iste praecedentibus designabatur exemplis. Hinc est quod Iacob in utero conflicuts agit, praeripit et triumphos. Hinc est quod in utero Thamar gemini de primatur honore proeliantur, retardant partus, nec ante lucem cupiunt videre quam vincere. Hinc est quod Iohannes exultat, et ante suo occurrit auctori, genitricis ex utero quam procedat".

${ }^{44}$ Sermo 68,11. CCL 24A, s. 411: „Aut quis poterit tanti conceptus referre sacramentum, ubi virgo mater parit orbe cotidie?".

${ }^{45}$ Sermo 72,2. CCL 24A, s. 430: „Dico ergo, et vos in utero adhuc penetrali voce compello, provida exhortatione praemoneo, ut antequam videatis matrem, vocetis istius patrem, ante blandimenta matris patris tendatis et festinetis ad regnum; ante patris perveniatis ad panem, quam matris ad ubera pendeatis; nec in vos quicquam sibi aut matris necessitas aut aetatis tempora vindicent, sed in vobis totum divino patri, totum caelesti respondeat et occurrat auctori".

${ }^{46}$ Sermo 73,3. CCL 24A, s. 449: „Numquid sic relinquendi sunt iam nutriti, ut non patris cura, patris manu, patris regantur arbitrio, et ita matris Consilio, matris fide muniantur, ut non humana solum, sed etiam divinam prudentiam percipiant et praeripiant salutarem?”

${ }^{47}$ Sermo 175, 4. CCL 24B, s. 1066 : „Marcellinus hodie vernaculi partus totum rapuit et conquisivit affectum. Circumstant filii, adsunt propinqui, cognatio tota concurrit, familia exultat omnis, et ipsa penetralia domus tripudiant et laetantur, quia videre oculis, suscipere manibus, hodie primum sanctae genitricis partum subolemque meruerunt. Ipsa quoque genetrix sponsa, mater et virgo, in ipso sponsi sui thalamo, in ipso coniunctionis suae cubiculo genuisse, nova gratulatione miratur". 
Ponieważ jedną z istotnych cech macierzyństwa Kościoła jest świętość, dlatego rodzenie do nadprzyrodzonego życia nowych chrześcijan było uważane za święte. Nie dziwi zatem, że Kościół był określany przez biskupa Rawenny mianem „święta matka Kośció’”48, „święta rodzicielka”49 bądź „matka świętych”"50.

Jedną z cech duchowego macierzyństwa Kościoła jest jego dziewiczy charakter. Kościół, rodząc chrześcijan do nowego życia, zachowuje swoją integralność. „Szczęśliwa matka Kościół, która was kontempluje, i pozostając dziewicą dziwi się, że was zrodziła w tak cudowny sposób" ‘51.

\section{b) Kościół a Maryja}

Autorzy chrześcijańskiego antyku, pisząc na temat duchowego macierzyństwa, szybko odkryli zachodzącą analogię między Kościołem a Błogosławioną Dziewicą Maryją. Ojcowie greccy uważali, że tajemnica dziewiczego poczęcia i porodzenia Chrystusa znalazła kontynuację w życiu Kościoła. Świadczą o tym między innymi Klemens z Aleksandrii ${ }^{52}$ i Grzegorz z Nyssy ${ }^{53}$, którzy pojęcia virgo, mater odnosili bądź to do Kościoła, bądź do Matki Jezusa. Wśród autorów łacińskich wspomnianą analogią posługiwali się św. Zenon z Werony ${ }^{54}$, św. Ambroży ${ }^{55}$ i św. Augustyn ${ }^{56}$.

W eklezjologii św. Piotra Chryzologa tajemnica poczęcia i porodzenia Chrystusa z Dziewicy Maryi stała się kluczem hermeneutycznym, za pomocą którego wyjaśniał on uświęcającą misję Kościoła. W takiej perspektywie został odczytany sakrament chrztu św.

Prawie zrodzeni, jak powiedzieliśmy, na podobieństwo naszego Pana, ponieważ bez wątpienia zostaliśmy podobnie jak On poczęci przez dziewicę, Duch napełnił nas

${ }^{48}$ Sermo 128,3. CCL 24B, s. 791: „Egit, egit ecclesia sancta mater”.

${ }^{49}$ Sermo 175, 4. CCL 24B, s. 1066: ,[...] hodie primum sanctae genetricis partum subolemque meruerunt".

${ }^{50}$ Sermo 105,5. CCL 24A, s. 653: „Haec quae modo est sanctorum genitrix, ecclesia sancta filiorum $[\ldots] "$.

${ }^{51}$ Sermo 72,3. CCL 24A, s. 431: „Ecclesia felix mater, quae nos tales respicit, quae cum virgo permanet, genuisse tantos vos et taliter se miratur”. Ponadto Sermo 130, 2. CCL 24B, s. 798: „Tales generat perpetuae virginitatis copula, tales generat caelestis ista coniunctio, sexus nescia, conceptus conscia, ignara partus, corruptionis ignara, pudore integra, integritate clausa, casta pignoribus, integritate diffusa".

${ }^{52}$ Klemens Aleksandryjski, Paedagogus I, 6, PG 8, 300.

${ }_{53}^{53}$ Grzegorz z Nyssy, In Christi resurrectionem I, PG 46, 604.

${ }^{54}$ Zenon z Werony, Tractatus XXXIII, PL 11, 479: „Haec renovatio, haec resurrectio, haec vita aeterna, haec est mater omnium, quae nos adunatos, ex omni gente et natione collectos, unum postmodum efficit corpus".

${ }_{55}$ Ambroży, De institutione virginis, XIV, 89-90, PL 16, 326-327: ,[...] continens sibi in omnibus Christi ortus ex Virgine".

${ }^{56}$ Augustyn, Sermo CCXIII, 7, PL 38, 1064. „Virgo est ergo Ecclesia: virgo est, virgo sit”. 
życiem, skromność nosiła nas w łonie, integralność nas zrodziła, niewinność nas karmiła, pouczała nas świętość, wychowała nas cnota. Bóg nas zaadoptował jako synów, a my nosimy w sobie cały obraz, całe podobieństwo naszego Stworzyciela ${ }^{57}$.

\section{c) Kościól a Eucharystia}

Nauka o Kościele biskupa Rawenny, oprócz aspektu maryjnego, odznacza się również silnie zarysowanym wymiarem eucharystycznym ${ }^{58}$. Ofiara Chrystusa, która uobecnia się codziennie na ołtarzu, uświęca Kościól ${ }^{59}$. Kaznodzieja utożsamia Eucharystię z Chrystusem i kilkakrotnie podkreśla, że ów sakrament nie tylko gładzi nasze grzechy, lecz staje się codziennym pokarmem w ziemskim pielgrzymowaniu do królestwa niebieskiego ${ }^{60}$. W tej perspektywie wspólnota Kościoła jest miejscem udzielania się Chrystusa eucharystycznego ${ }^{61}$, dzięki któremu staje się wspólnotą niebiańską ${ }^{62}$.

\section{4. Świętość a jedność Kościoła}

Pisarze antyku chrześcijańskiego często podkreślali ścisłą zależność pomiędzy świętością Kościoła a jego jednością. Jedność ukazywano jako owoc panującej we wspólnocie wzajemnej miłości. $Z$ tego względu herezje i schizmy, pro-

${ }^{57}$ Piotr Chryzolog, Sermo 117,5. CCL 24A, 711: ,sicut diximus, iam renati, quos utique concepit virgo, vivificavit spirytus, portavit pudor, genuit integritas, nutrivit inocentia, edocuit sanctitas, virtus exercuit, deus adoptavit in filios, imaginem totam, totam similitudinem nostri portemus auctoris". Podobnie Sermo 72, 3, CCL 24A, 431. Por. B. Kochaniewicz, La Vergine Maria nei sermoni di san Pietro Crisologo, Roma 1998, s. 252.

${ }^{58}$ D. Kasprzak, Duszpasterze V wieku, dz. cyt., s. 139.

${ }^{59}$ Piotr Chryzolog, Sermo 67,7. CCL 24A, 404-405: „«Ego sum panis qui de caelo descendi». Ipse est panis qui est satus in virgine, fermentatus in carne, in passione confectus, fornace coctus sepulchri, in ecclesiis conditus, inlatus altaribus caelestem cibum cotidie fidelibus subministrat". Sermo 34, 3. CCL 24, 408: „Audiant christiani, qui quotidie corpus Christi attingunt”. Według A. Olivara określenie „quotidie” należałoby pojmować raczej jako zwyczaj przyjmowania ciała Pańskiego podczas każdej mszy św. A. Olivar, La Eucaristía en la predicación de San Pedro Crisólogo, "La Ciencia Tomista" 272 (1959), s. 617-618.

${ }^{60}$ Piotr Chryzolog, Sermo 71,7: CCL 24A, 426-427: „Sed quia ipse est panis qui de caelo descendit, qui legis et gratiae mola aptus est in farinam, qui crucis confectus est in passione, qui magno pietatis fermentatus est sacramento, qui consparsionis levamentum sustulit de sepulchro, qui ut divinitatis suae calore coqueretur ipse cibanum decoxit inferni, qui ad caelestem cibum cotidianus ecclesiae deferetur ad mensam, qui in remissionem frangitur peccatorum, qui edentes se perpetuam pascit et enutrit ad vitam, hunc panem cotidie nobis dari petimus, illo in die perpetuo perfruamur".

${ }^{61}$ Sermo 67,7. CCL 24A, 404-405: „Ipse est panis, [...] inlatus altaribus caelestem cibum cotidie fidelibus subministrat”. Sermo 95, 3: CCL 24A, 586: ,[...] sed corpus suum ecclesiae transmisit ad mensam, ut esset caelestis caro manducaturis gentibus ad salutem".

${ }^{62}$ Sermo 31,3. CCL 24, 180: „Christus ergo, qui tunc cclesiam disponsabat, indulgebat se mensis, conviventibus non negabat; humanum, communem, blandum se pia caritate reddebat, donec divinis humana coniungeret, et faceret de terrena societate caeleste consortium". Por. D. Kasprzak, Duszpasterze V wieku, dz. cyt., s. 138. 
wadzące do niszczenia jedności Kościoła, były surowo zabraniane i potępiane ${ }^{63}$. Według św. Ambrożego, na przykład, ci, którzy rozrywali Kościół i odłączali się od niego, dopuszczali się niewybaczalnego grzechu ${ }^{64}$.

Biskup Rawenny akcentował dwa wymiary jedności. Pierwszy aktualizował się podczas zgromadzeń liturgicznych. Stąd kaznodzieja zachęcał wiernych do większego zaangażowania w zgromadzenia liturgiczne, krytykując pobożność indywidualną prowadzącą do rozdarcia w Kościele lokalnym ${ }^{65}$.

Natomiast drugi wymiar jedności realizował się dzięki łączności wiernych ze swoim pasterzem: ,święta matka Kościół działa w taki sposób, aby nie być oddzielona od własnego biskupa" ${ }^{66}$.

Jednocześnie należy podkreślić, że kaznodzieja, rozważając tajemnicę świętości Kościoła, dostrzega również jego słabość i grzeszność. Komentując ewangelię o kobiecie chorej na upływ krwi (Mt 9,20-21), stwierdził, że jest ona figurą Kościoła zranionego przez grzech pierworodny człowieka, który tracił swoją krew $^{67}$. Eklezja jest reprezentowana również przez jawnogrzesznicę. Wyjaśniając perykopę Łk 7,36-37, Piotr z Rawenny wymienił cały katalog grzechów (niewiarę, nieprawość, pychę, kłótnie, lichwę, cudzołóstwo), krytykując tym samym zachowanie wiernych.

„Oto niewiasta, która w mieście była grzesznicą”. Jaka niewiasta? Bez wątpienia Kościół. „W mieście grzesznica”. Jakiego miasta? Tego, o którym prorok powiedział: „W jaki sposób miasto wierne Syjon, stało się grzeszne”? [...] Zatem w mieście, otoczonym murem niewiary, bronionym przez moc pychy, podzielonym przez place nieprawości, zamkniętym przez bramy kłótni, przedstawianym przez zwodnicze tańce, zatwardziałym przez kamienie lichwy, obciążonym przez trudy interesów, zbezczeszczonym przez domy publiczne, to znaczy przez świątynie bożków. Tą niewiastą jest Kościół, obciążony oskarżeniami, będącymi konsekwencją obrzydliwości popełnionych w przeszłości przez grzeszników ${ }^{68}$.

${ }^{63}$ J.N.D. Kelly, Poczqtki doktryny chrześcijańskiej, Warszawa 1988, s. 300.

${ }^{64}$ Tamże, s. 303.

${ }^{65}$ Sermo 132, 4. CCL 24B, s. 811-812: „Ubi sunt qui ecclesiae conventum praesumunt posse contemni, et solitarias preces venerandae congregationi autumant anteferri, si duobus vel tribus compositis medium se futurum, et omnia se promittit quae postulatus fuerit praestaturum? Quid non dat plurimis? Quid in conciliis et congregatione sanctoruum poscentibus denegabit".

${ }^{66}$ Sermo 128,3. CCL 24B, s. 791: „Egit, egit ecclesia sancta mater, ut nusquam a suo separaretur antistite".

${ }^{67}$ Sermo 35,5. CCL 24, s. 204: „Ista est, fratres, ista est, ista est eccclesia, quae primo hominis vulnerata peccato, toto fluebat sanguine".

${ }^{68}$ Piotr Chryzolog, Sermo 95, 4. CCL 24A, s. 587: „«Et ecce», inquit, «mulier, quae erat in civitate peccatrix». Quae mulier? Ecclesia sine dubio. «In civitate peccatrix». Civitate qua? Illa, de qua dixerat propheta: «Quomodo facta est meretrix civitas fidelis Sion». [...] In civitate ergo perfidiae septa muris, superbiae viribus conmunita, distincta iniquitatum plateis, obserata contradictionum portis, depicta iniquitatum plateis, indurata silicibus usurarum, negotiorum laboribus adgravata, infamata lupanaribus, id est, idolorum templis, mulier haec, id est, ecclesia, gravissimum trahebat reatum ex tanta praecedentium conluvie peccatorum". 
Przytoczony fragment pozwala stwierdzić, że zdaniem kaznodziei z Rawenny, grzechy popełnione przez wiernych prowadzą do utraty duchowego piękna Kościoła oraz do osłabienia jego jedności.

\section{Kościół a zbawienie}

Zagadnienie świętości Kościoła łączy się również z kwestią możliwości zbawienia poza nim. To zagadnienie było już podejmowane przez teologów w III wieku. Orygenes, komentując scenę przybycia zwiadowców izraelskich do domu jawnogrzesznicy Rahab, stwierdził, że „poza Kościołem, nikt się nie uratuje"69. Podobną opinię wyraził św. Cyprian z Kartaginy: „Nie dojdzie do nagrody Chrystusa ten, kto porzuca Kościół Chrystusa"70.

Nauczanie Piotra Chryzologa w tej kwestii nie odbiega od powszechnej opinii ojców Kościoła. Kaznodzieja, opisując tajemnicę Kościoła, posłużył się obrazem statku, przemierzającego wzburzone morze tego świata w drodze do portu zbawienia $^{71}$. Wykorzystana analogia pozwoliła z jednej strony zwrócić uwagę na nieustanne zagrożenie i niebezpieczeństwo, z jakim zmaga się Kościół, z drugiej zaś na nieustanną obecność Chrystusa, który jest gwarantem zbawienia. Jego obecność na pokładzie statku ${ }^{72}$ jest niezbędna dla Kościoła ${ }^{73}$. To On kieruje okrętem, prowadząc go do portu zbawienia. Jedynie On, jako sternik statku, potrafi uspokoić fale tego świata i zapewnić bezpieczną podróż ${ }^{74}$.

${ }^{69}$ Orygenes, Homiliae in Jesu nave, homilia III, 4. PG 12, 861-8142. SCh 71, Paris 1960, ed. A. Jaubert, s. 136, 138.

${ }^{70}$ Cyprian, De catholicae ecclesiae unitate VI, PL 4, 503: „Non perveniet ad Christi praemia, qui relinquit Ecclesiam Christi”. Zob. J. Quasten, Patrology, vol. II, Notre Dame, 1952, s. 351, 373.

${ }^{71}$ Piotr Chryzolog, Sermo 20,2. CCL 24, s. 117: „Ubi Christus ecclesiae suae navem mare saeculi transferatus ascendit, gentium flabra, Iudaeorum turbines, persecutorum procellae, vulgi nubes, daemonum nebulae sic ruerunt, ut totius mundi fieret una tempestas".

Sermo 20,4. CCL 24, s. 119: „Hinc est quod navicula Christi nunc tollitur ad caelum, nunc in trepidationum ima descendit, nunc Christi regitur viribus, nunc formidine iactatur, nunc operitur fluctibus passionum, nunc confessionum remigiis enatat".

72 Sermo 32,5. CCL 24, s. 185: „Sed quia Iesus deserviente navicula, id est, ecclesia, sequestratur a confusione turbarum, et christaini populi gubernatur residdet indefessus vario genere medendi; et imperavit ventis et mari, ut tantam tranquillitatis oboedientia conquiescant [...]".

Sermo 50,2. CCL 24, s. 277: „Christus ecclesiae suae navem saeculi fluctus semper mitigaturus ascendit, ut credentes in se ad caelestem patriam tranquilla navigatione perducat". Por. H. Rahner, Simboli della Chiesa. L'ecclesiologia dei Padri, Cinisello Balsamo 1995, s. 512.

${ }^{73}$ Sermo 50,2. CCL 24, s. 278: „Non ergo Christus indiget nave, sed navis indiget Christo, quia sine caelesti gubernatore navis ecclesiae per mundanum pelagus tali et tanto discrimine ad caelestem portum non valet pervenire".

${ }^{74}$ Sermo 20,1. CCL 24, s. 117: „Hinc est quod discipuli postea quam viderunt sibi industriam nauticam deperisse, in se maria saevire, se fluctus petere, adversum se ventorum turbines convenisse, ad ipsum gubernatorem rerum, vectorem mundi, elementorum magistrum, trepidi confugerunt, petentes ut sedaret fluctus, periculum submoveret, salutem redderet desperatis. Denique ubi iussio sola 
Zarysowaną przez Piotra Chryzologa zbawczą rolę Kościoła należy rozumieć w sposób ekskluzywny. Poza okrętem znajduje się jedynie wzburzone morze, stąd wyłącznie na pokładzie statku-Kościoła można dotrzeć do portu zbawienia. Niniejsza opinia została jeszcze bardziej uwypuklona poprzez obraz arki Noego, proroczo zapowiadający zbawczą rolę Kościoła ${ }^{75}$.

\section{Zakończenie}

Analiza eklezjologii Piotra Chryzologa pozwoliła na sformułowanie następujących wniosków.

Nauka o Kościele, zawarta w kazaniach biskupa Rawenny, odznacza się fragmentarycznością, co w konsekwencji rzutuje na jej niekompletność. Dokonana synteza rozsianych w wielu homiliach elementów doktryny pozwala stwierdzić, że eklezjologia Złotosłowego kaznodziei nie odznacza się oryginalnością. Podejmowane tematy były przedmiotem opracowań wcześniejszych ojców Kościoła: ukazanie Chrystusa jako fundamentu świętości Kościoła, podkreślenie uświęcającej roli sakramentów, zwrócenie uwagi na fakt, że poza Kościołem nie ma zbawienia czy też akcent położony na jedność wiernych ze swoim biskupem, były tematami dobrze znanymi w ówczesnej literaturze patrystycznej. Biorąc pod uwagę pastoralny wymiar nauczania biskupa Rawenny, należy stwierdzić, że nadrzędnym celem redagowanych przez niego kazań nie było przekazywanie wiernym kompletnej doktryny na temat Kościoła: jego eklezjologia była podporządkowana celom wybitnie duszpasterskim, co może tłumaczyć jej fragmentaryczność i niekompletność.

Osiaggnięte wyniki badań, pomimo braku oryginalnych aspektów, uzupełniają obraz nauki o Kościele o słabo znaną do tej pory doktrynę zawartą w kazaniach Piotra Chryzologa.

\section{Holiness of the Church According to Sermons of St. Peter Chrysologus}

\section{Summary}

The article Holiness of the Church according to Sermons of St. Peter Chrysologus presents one aspect of the ecclesiology of the bishop of Ravenna. Among the most popular questions, which are evidenced in his theological reflection, it is necessary to evidence, that Church Fathers focus

addixit mare, recussit ventos, tulit turbines, dedit quietem, navigantes ipsum esse omnium sentiunt, credunt, fatentur auctorem". Zob. H. Rahner, Simboli della Chiesa, dz. cyt., s. 568.

${ }^{75}$ Sermo 163, 3. CCL 24B, s. 1006: „Nam quicquid Noe, vector novi saeculi, saeculi servavit ad semen, quicquid in aere volitat et fertur, quicquid gignitur et vivit in terra, quicquid in aquas est et movetur [...]". Typologia eklezjologiczno-soteriologiczna arki Noego była rozpowszechniona wśród ojców Kościoła. Zob. H. Rahner, Simboli della Chiesa, dz. cyt., s. 865-932. 
their attention on an ontological aspect of the Church's holiness which finds its foundation in Christ. Frequent references to ideas of the Mystical Body of Christ or the Church as a spouse of Christ confirm our opinion. It is necessary to admit that these themes, like other questions, developed in Chrysologus's sermons (the role of the sacrament or belief that there is no salvation outside the Church) are already known in the patristic literature. Therefore the ecclesiology of the bishop of Ravenna is not original. However, taking into consideration the pastoral dimension of his teaching, it is clear that the objective of his sermons was different than to present an ecclesiological treatise.

The results of analytical researches allow to complete the picture of the doctrine of the Church by its unknown aspect, contained in the teaching of the bishop of Ravenna.

\section{Keywords}

Peter Chrysologus, ecclesiology, sermons, holiness, teaching

\section{Słowa kluczowe}

Piotr Chryzolog, eklezjologia, kazania świętość, nauczanie

\section{Bibliografia}

Bogacki H., Kościół jako Ciało Mistyczne wedtug św. Hieronima, „Roczniki Teologiczno-Kanoniczne" 5(1958) z. 4, s. 37-53.

Camelot P.T., Die Lehre von der Kirche: Väterzeit bis ausschliesslich Augustinus, Freiburg 1970.

Częsz B., Zwiazek Ducha Świętego z Kościołem w ujęciu świętego Ireneusza i w interpretacji montanistycznej, Poznań 1991.

Drączkowski F., Kościót - agape wedtug Klemensa Aleksandryjskiego, Lublin 1983.

Dublanchy E., L'Église, w: Dictionnaire de Theologie Catholique, t. 4, pars 2, kol. 2108-2152.

Grodecki T., Dlaczego wszyscy musza być zbawieni? Zbawienie i Kościół u Grzegorza z Nyssy, w: Kościót, świat i zbawienie we wczesnym chrześcijaństwie, red. J. Naumowicz, Warszawa 2004, s. 111-118.

Kaczmarek T., Ecclesia sponsa Christi w nauczaniu św. Cypriana, w: Kościót, świat i zbawienie we wczesnym chrześcijaństwie, red. J. Naumowicz, Warszawa 2004, s. 103 -110 .

Kasprzak D., Duszpasterze V wieku. Studium porównawcze myśli pasterskiej św. Piotra Chryzologa i Salwiana z Marsylii, Kraków 2008.

Kasprzak D., Kościół IV/V wieku - pomiędzy instytucja Kościoła imperialnego a ideałem Kościoła apostolskiego, w: Kościót starożytny - Królestwo Chrystusa i instytucja, red. F. Drączkowski, Lublin 2010, s. 135-154.

Kelly J.N.D., Poczatki doktryny chrześcijańskiej, Warszawa 1988.

Kochaniewicz B., La Vergine Maria nei sermoni di san Pietro Crisologo, Roma 1998.

Kołosowski T., Kościót jako wspólnota zbawienia wedtug Hilarego z Poitiers, w: Kościól, świat i zbawienie we wczesnym chrześcijaństwie, red. J. Naumowicz, Warszawa 2004, s. $119-129$. 
Libera P., Biblijne obrazy Kościoła w pismach św. Ambrożego na przykładzie traktatu „De Isaac et anima”, w: Kościót świat i zbawienie we wczesnym chrześcijaństwie, red. J. Naumowicz, Warszawa 2004, s. 75-85.

Olivar A., La Eucaristía en la predicación de San Pedro Crisólogo, "La Ciencia Tomista" 272(1959), s. 605-628.

Palardy B., The Church and the Synagogue in the Sermons of St. Peter Chrysologus, The Catholic University of America, Washington 1992.

Pałucki J., Trynitarny wymiar Kościoła. Studium patrystyczne, Lublin 2007.

Pałucki J. Eklezjologia Ojców Kościoła, w: Kościól w czasach Jana Pawła II, red. M. Rusecki, K. Kaucha, J. Mastej, Lublin 2005, s. 99-112.

Prus W., Spór o «Ecclesia sancta» w Afryce na podstawie tacińskich przekazów patrystycznych III i IV wieku, Poznań 2013.

Quasten J., Patrology, vol. 2, Notre Dame 1952.

Rahner H., Simboli della Chiesa. L'ecclesiologia dei Padri, Cinisello Balsamo 1995.

Scimè G., Giudei e cristiani nei sermoni di san Pietro Crisologo, Roma 2003.

Staniek E., Kościót - wspólnota czy społeczność. Zarys eklezjologii pierwszych trzech wieków, „Vox Patrum” 10(1986), s. 203-218.

Staniek E., Widzialny aspekt Chrystusowego Kościoła wedtug Ambrozjastra, „Analecta Cracoviensia 10(1978), s. 183-210.

Staniszewski W., Kościół jako Ciało Mistyczne Chrystusa wedlug św. Augustyna, Lublin 1936.

Vogt H.J., Ecclesiologia, w: A. Di Bernardino, Dizionario patristico e di antichità cristiane, vol. 1, Casale Monferrato 1983, koll. 1049-1062.

Wojtczak J., Kościót jako «grex» w Sermones Piotra Chryzologa, w: Kościót, świat i zbawienie we wczesnym chrześcijaństwie, red. J. Naumowicz, Warszawa 2004, s. 154-158.

Ambroży, De institutione virginis. PL 16, koll. 305-334.

Ambroży, Epistula LXXVI. PL 16, koll. 1259-1267.

Augustyn, Epistula CXL, 18. PL 33, koll. 538-577.

Augustyn, Sermo CCXIII. PL 38, koll. 1060-1065.

Bazyli Wielki, Homilia super Psalmum XLIV. PG 29, koll. 388-413.

Cyprian, De catholicae ecclesiae unitate. PL 4, koll. 493-520.

Cyprian, Epistula 73. CCL 3, Turnholti 1994, s. 529-562.

Cyprian, Epistula 75. CCL 3, Turnholti 1994, s. 581-604.

Grzegorz z Nazjanzu, Oratio II. PG 35, koll. 407-513.

Grzegorz z Nyssy, In Christi resurrectionem. Oratio I. PG 46, koll. 600-628.

Ireneusz z Lyonu, Adversus haereses. Liber III. PG 7, koll. 643-972.

Jan Chryzostom, In Epistolam I ad Corinthios, Homilia XXXII. PG 61, koll. 263-276.

Jan Chryzostom, In espistolam ad Ephesios. Homilia XX. PG 62, koll. 135-150.

Klemens z Aleksandrii, Paedagogus. Liber I. PG 8, koll. 249-376. 
Optat z Milewy, Traité contre les Donatistes, t. II (livres III a VII). SCh 413, Paris 1996, s. 8-244.

Orygenes, Contra Celsum. PG 11, koll. 641-1652.

Orygenes, Homiliae in librum Jesu nave. Homilia III. PG 12, koll. 856-842.

Orygenes, In Canticum canticorum. PG 13, koll. 61-198.

Orygenes, In Exodum. Homilia IX. PG 12, koll. 361-369.

Piotr Chryzolog, Sermo 60. CCL 24, s. 335-340.

Zenon z Werony, Liber II. Tractatus XXXIII. PL 11, kol. 479. 